\title{
Unemployment Duration and Personality
}

\author{
Selver Derya UYSAL ${ }^{\mathrm{a}, *}$, Winfried POHLMEIER ${ }^{\mathrm{b}}$ \\ ${ }^{a}$ University of Konstanz, CMS \\ ${ }^{b}$ University of Konstanz, CMS, RCEA, ZEW
}

\begin{abstract}
This paper focuses on the role personality traits play in determining individual unemployment duration. We argue that a worker's job search intensity is decisively driven by her personality traits, reflected in her propensity to motivate and control herself while searching for a job. Moreover, personality traits, in as far as they can be signaled to a potential employer, may also enhance the probability of receiving and accepting a job offer.
\end{abstract}

For our econometric duration analysis, we use the well-accepted taxonomy "Big Five" to classify personality traits. Based on individual unemployment data taken from the German Socio-Economic Panel (SOEP) our empirical findings reveal that the personality traits Conscientiousness and Neuroticism have a strong impact on the instantaneous probability of finding a job, where the former has a positive effect and the latter has a negative effect. The direction of the effect on the subsequent employment duration is the opposite. We do not find any significant effects of the personality traits Extraversion and Agreeableness on the duration of unemployment. The personality trait Openness eases finding a job only for female unemployed workers and workers with migration background.

Keywords: Unemployment Duration, Personality Traits, Big Five, Duration

Analysis

JEL classification: J64, C41,

PsycINFO classification: 3100,3600

\footnotetext{
*Corresponding author. Department of Economics, Box D124, University of Konstanz, 78457 Konstanz, Germany. Phone ++49-7531-88-2556, Fax -4450. Financial support by the German Research Foundation (DFG), the Center for Psychoeconomics and the Center of Quantitative Methods and Survey Research (CMS) at the University of Konstanz is gratefully acknowledged.

Email addresses: selver.uysal@uni-konstanz.de (Selver Derya UYSAL), winfried.pohlmeier@uni-konstanz.de (Winfried POHLMEIER)
} 


\section{Introduction}

The role played by personality traits in an individual's success on the labor market has drawn considerable attention in labor economics. Recent empirical findings show significant effects of personality on various economic outcomes, such as earnings, labor force participation, employment probability. Comparatively, little is known, however, about how personality traits affect the transition period from unemployment to the employment. We contribute to the discussion on the relation between personality and economic outcomes by looking at how the unemployment duration differs for people with different personality traits.

Traditionally, labor economists focus on incentive schemes, the role of labor market institutions and educational attainment in their analysis of the individual transition out of unemployment. Apart from the usual socio-economic control variables, individual heterogeneity is regarded as being important, particularly from an econometric point of view, but is usually considered to be unobservable. Ignoring individual differences such as personality traits, however, leads to the well-known spurious duration dependence of unemployment and possibly to misleading evaluations concerning public measures to increase the employability of the unemployed. Besides the role of the economic incentive scheme, which is central to all job search models, it is obvious that a number of additional, usually unobservable factors determine the success to find a job. For instance, a worker's job search intensity is not solely driven by economic incentives but also by the propensity to motivate and control herself while searching for a job. Moreover, personality traits, in as far as they can be signaled to a potential employer, may also enhance the probability of receiving and accepting a job offer. Therefore based on a conventional job search model with endogenous job search effort, we argue that the channels through which personality traits may effect a person's transition from unemployment to employment are many- 
fold and may not only be linked to preferences (e.g. risk attitude, self-regulation), search costs (disutility of search) or the job offer arrival rate. ${ }^{1}$ The individuals with certain traits might face lower search costs, which in turn may increase the optimum search intensity and the reservation wage. More intense search will increase the number of offers received, however the net effect on the unemployment duration is ambiguous due to the increased reservation wage. Workers with different personality traits even may face different wage offer distributions. For instance, the wage offer distribution workers with a high degree of Openness may have fatter tails than the one for workers with a low degree of Openness. Therefore from a theoretical point of view the sign of effect of certain personality traits is ex-ante undetermined and remains to be tackled empirically.

In the following we use a reduced form approach to assess how different personality traits affect a unemployed individuals instantaneous probability of finding a job. In particular, we try to work out the extent to which different dimensions of personality traits have an effect on transitions out of unemployment and on the duration of this subsequent employment. As mentioned in Bowles et al. (2001), traits might have different effects for women and men, or different ethnic or language groups. Therefore, we check the robustness of our findings by considering different subpopulations of the labor market (male and female workers, immigrants and natives). Furthermore, following the results by Barrick \& Mount (1991), different occupations requires different types of personality traits, we also explore the importance of personality traits on unemployment and employment duration for various occupational groups and sectors. By estimating employment durations for the formerly unemployed workers in our sample, we provide empirical evidence to what extend

\footnotetext{
${ }^{1}$ For a search theoretical discussion see for example Mortensen \& Pissarides (1999), Pissarides (2000) among others.
} 
the same personality traits are beneficial in keeping the job.

The outline of the paper is as follows. Section 2 briefly reviews previous research on the relationship between personality traits and individual labor market outcomes. Section 3 focuses on the sample and some descriptive evidence. Section 4 shortly describes the econometric methods used and elaborates on the empirical results. Finally, Section 5 summarizes the main results and concludes the paper.

\section{Personality Traits and Previous Findings}

Our empirical analysis is based on the well-accepted taxonomy known as the "Big Five" of Norman (1963) for classifying personality traits (see John \& Srivastava, 1999, and the references given therein for the evaluation of the Big Five personality traits). "Big Five" model of personality is a hierarchical organization of personality traits in terms of 5 basic dimensions: "Extraversion, Agreeableness, Conscientiousness, Neuroticism, and Openness to Experience". After more than four decades, the "Big Five" taxonomy is still the most accepted one, not only in personality and social psychology, but also in other fields such as industrial- and organizational psychology and personal economics.

A considerable number of studies analyze the relationship between personality and various economic outcomes in social science fields such as sociology, social psychology, personal psychology and economics (for a review of the psychology and sociology literature on this topic see Ozer \& Benet-Martnez, 2006; Farkas, 2003). Heckman et al. (2006) find significant effects of personality traits, such as self-control and selfesteem, on wages. They show that both traits are valued for both men and women by the labor market, but find some gender differences over different sectors. Mueller \& Plug (2006) estimate the effect of personality on male and female earnings using 
an US data set. In their study lower scores in Agreeableness and Neuroticism and higher scores in Openness are associated with higher earnings for males, whereas higher scores in Conscientiousness and Openness have a positive effect on the earnings of females. In strong contrast to their results is the Swedish study by Zetterberg (2005), who does not find any difference in returns to personality traits (self-esteem) across genders. He, however, points out that the returns to personality traits vary over the earning distribution. This result is consistent with the view that the returns to personality traits vary over different occupational positions and sectors. Nyhus \& Pons (2005) find that Neuroticism is negatively associated with the wage of both women and men, while Agreeableness is negatively associated with lower wages only for women for the Netherlands. Using a US data set, Mohanty (2009) shows that positive attitude positively affects the earnings directly as well as indirectly through schooling. Using the same information on the Big Five as in our study, Heineck \& Anger (2010) find significant effects of personality traits on wages for Germany.

Labor market participation and employment probabilities are major economic outcome variables which have been investigated in their relationship to personality traits. The study by Wichert \& Pohlmeier (2010) focuses on the effect of the Big Five on female labor force participation. They show, that with the exception of Agreeableness, all other Big Five personality traits have statistically significant effects on the participation probability. Conscientiousness and Extraversion affect the participation probability positively, whereas Openness and Neuroticism decrease the participation probability. They also show that the interindividual traits Extraversion and Agreeableness have strong effect on wages of women where the former effect is positive while the latter is negative. Mohanty (2010) investigates the effect of positive attitude on the participation decision and employment probability. His results indicate that these probabilities are determined partly by positive attitude of the 
worker. He, however, also emphasizes the gender differences of the effects.

Further studies, especially in the psychology literature, concentrate on the link between personality traits and other economically relevant outcome variables like job performance, job search behavior, job change frequency, absenteeism etc. (see Tokar et al., 1998, and their references for a review). These studies show such outcomes are also related to the personality. Although, these studies are difficult to generalize due to the restricted samples they use, they signal the importance of the personality traits in determining various economic outcomes.

In light of previous empirical findings on the effects of personality on individual labor market performance, we expect that individual unemployment duration is affected by personality through various channels. The channels can be worked out in a basic search theoretical model with the following elements: search cost and the job arrival rate as functions of search intensity, and the reservation wage. In such a framework, these factors determine the hazard rate of an individual job searcher. Intuitively, but also based on previous empirical findings, it is very likely that these factors are determined directly and/or indirectly by personality. The cost of the search depends on how efficient one can search for a job. Schmit et al. (1993) show that Conscientiousness and Openness are positively correlated with an efficient job search behavior, whereas Neuroticism has a negative correlation. However, the costs of the search also influences the reservation wage which, in turn, decreases the job acceptance probability. Personality traits signalled to a potential employer, on the other hand, will have different effects on the wage offers depending on how valuable these traits are for the job under consideration. Moreover, individuals with certain traits will have different bargaining power and this will also affect the transition from unemployment to employment. Since personality traits influence the interac- 
tion between job searcher and employer and are likely to affect the employer's hiring policy, linked employer-employee data would be desirable to disentangle the complex interaction in the hiring process which would still require strong identifying assumptions (restrictive functional form assumptions, exclusion restrictions etc.). Given our data limitations, we propose the estimation of a reduced form to investigate the overall relationship between individual unemployment duration and personality traits. Similar to many related studies using self-reported personality trait measures, potential endogeneity problems should not be ignored. As mentioned by Carneiro \& Heckman (2004), self-reported ex-post assessments are likely to be both causes and consequences of economic outcomes. Although there are several studies in the psychology literature which argue that the personality traits are stable over the life cycle and are not seriously affected by life outcomes (see Costa \& McCrae, 1988; McCrae \& Costa, 1994, and the references given therein), some empirical studies provide evidence supporting the view that personality traits change the over life cycle (Srivastava et al., 2003; Borghans et al., 2008). Despite the yet inconclusive discussion on the stability of the personality traits, inclusion of the measures of personality traits in the economic analysis is very important in different respects. First, personality measures are useful to control for unobserved individual heterogeneity (Boyce, 2010; Anand et al., 1991). Second, as emphasized by Carneiro \& Heckman (2004) and given that this literature is relatively new, these studies are essential to shedding light on the importance of personality in determining economic outcomes.

\section{Data}

Our empirical study is based on data from the German Socio-Economic Panel (SOEP). The SOEP is a wide-ranging representative longitudinal study of private households. The Panel was started in 1984 with randomly selected adult respon- 
dents from West Germany. A random sample from East Germany is included after German reunification in 1990. Every year, there were nearly 11,000 households, and more than 20,000 persons sampled from residential population in Germany. Some of the many topics covered in SOEP include household composition, occupational biographies, employment and earnings. Aside from these topics, the 2005 wave of the SOEP includes a 15-item short version of the Big Five Inventory. The Revised NEO Personality Inventory (NEO PI-R), the most widely used psychological personality inventory, with 240 items is not tractable as a part of the very comprehensive SOEP survey due to the time constraints. Therefore, the 15-item short version is prepared according to the results of a pretest, which was conducted in 2004 on a number of different short item scales to test the Big Five approach. Gerlitz \& Schupp (2005) explain in detail the pretest procedure and the results of the reliability and validity analysis. The Cronbach's alpha reliabilities (Cronbach, 1951) reported in Gerlitz \& Schupp (2005) are: Openness 0.74, Conscientiousness 0.72, Agreeableness 0.53, Extraversion 0.62 and Neuroticism 0.57 . Although the reliability coefficients found in the literature are on average 0.80 (John \& Srivastava, 1999), these values of the coefficients do not necessarily indicate unreliability of the short inventory. As Mueller \& Plug (2006) and Heineck \& Anger (2010) mention the alpha reliability coefficients increase with the number of items. Given that there are three items per personality trait in the SOEP, the ratios found are satisfactory (see Dehne \& Schupp, 2007, for further investigation of the short item inventory in the SOEP).

Each wave of the panel contains retrospective monthly information about the individual employment history of the previous calendar year. Although the SOEP distinguishes between several categories of employment status, we aggregate this information into three distinct categories: unemployed, employed and out of labor 
force. $^{2}$ A person is defined to be unemployed (a job searcher) if she is currently not employed and has indicated that she is looking for a job.

Employment status refers to any kind of working activity: full time, part time or short working hours. Out of labor force, on the other hand, includes retirement, parental leave, school, vocational training and military service. Our sample only consists of individuals who experience unemployment spells with a subsequent employment spells. Transition from unemployment to employment is a situation in which the employment begins at the latest two months after the unemployment spell ends. We use SOEP data 1984-2007, such that we have information on the individuals entering unemployment between 1983 and 2006. We exclude individuals younger than 20 and older than 55 at the time of their entry into unemployment. This is done to avoid issues such as school and/or university enrollment as well as early retirement. We also exclude individuals from the sample for whom we did not have information concerning their Big Five personality traits or one of the other characteristics we use for our analysis. This leaves us with a sample of 4466 individual unemployment spells of 2735 individuals and 4191 employment spells of 2605 individuals. The difference in the number of individuals occurs due to the missing explanatory variables used in the analysis for the employment duration. Due to recurring unemployment, $35 \%$ of the observed unemployment and employment spells are multiple spells, which we treat for the sake of simplicity as independent

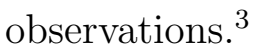

In order to measure personality traits, self-assessment questions on the Big Five are used from the 2005 wave of SOEP. The respondents are asked to assess fifteen

\footnotetext{
${ }^{2}$ Employment status used in this paper is self reported.

${ }^{3}$ Relegating multiple spells from the sample did not change our empirical findings qualitatively.
} 
statements which are related to the Big Five personality traits (see Table 1). The ordering of the statements during the interview was not clustered. The respondent has to indicate the degree of agreement with each statement on a 7-tier LikertScale from "strongly disagree" to "strongly agree". For each trait, there are three statements. Strong agreement with a statement is interpreted as meaning that the respondent possesses the corresponding trait heavily $(\oplus)$ or does not possess this trait $(\ominus)$ depending on the statement. We construct single indexes for each personality trait by adding up the numeric values of the answers of the three questions for each trait. "Strongly disagree" is worth one point and "I strongly agree" seven points for a question which has a positive association with the corresponding trait. If the question is negatively associated with the personality trait, we give one point for "I strongly agree" and seven for "I strongly disagree". Thus, the indexes of each trait range between three and twenty-one. All further variables used in this study are listed in Table A1 in Appendix A.

Table 1: The self-assessment questions in the SOEP 2005 wave

\begin{tabular}{l|l}
\hline "I see myself as someone who ... & \\
\hline \hline Extraversion: & $\ldots$ is communicative, talkative $\oplus$ \\
& $\ldots$ is outgoing, sociable $\oplus$ \\
& $\ldots$ is reserved $\ominus$ \\
\hline Agreeableness: & $\ldots$ has a forgiving nature $\oplus$ \\
& $\ldots$ is considerate and kind to others $\oplus$ \\
& $\ldots$ is sometimes somewhat rude to others $\ominus$ \\
\hline Conscientiousness: & $\ldots$ does a thorough job $\oplus$ \\
& $\ldots$ does things effectively and efficiently $\oplus$ \\
& $\ldots$ tends to be lazy $\ominus$ \\
\hline Neuroticism: & $\ldots$ is relaxed, handles stress well $\ominus$ \\
& $\ldots$ gets nervous easily $\oplus$ \\
\hline Openness: & $\ldots$ worries a lot $\oplus$ \\
\hline \hline
\end{tabular}

Note: $\oplus$ : positively related with the trait; $\ominus$ : negatively related with the trait 


\section{Unemployment Spells}

Table A2 of Appendix A contains the summary statistics of unemployment duration and personality traits for the overall sample and the subsamples we use in our analysis. ${ }^{4}$ Individual unemployment duration is longer for foreign workers than for Germans. There is also a significant difference in unemployment duration between male and female workers. Almost $40 \%$ of the unemployment spells end within 3 months. $80 \%$ of the unemployment spells are shorter than one year and only $3 \%$ of the unemployment spells last longer than 3 years. The self-assessment of male and female workers with respect to all Big Five dimensions differs significantly. Similarly, we find significant differences between German and foreign unemployed workers for Extraversion, Agreeableness and Openness. There are significant differences between blue-collar and white-collar workers for all the traits except for Conscientiousness. Traits associated with better job performance are more pronounced for white collar workers, while Neuroticism is more pronounced for blue collar workers. Similarly, there are also differences in personality traits across sectors showing that job choice is also determined by personality. As expected, unemployed individuals who formerly worked in the service sector reveal more Extraversion, Neuroticism, Openness and Agreeableness compared to workers from the construction or the manufacturing sector. This explorative finding makes it clear that individual differences in unemployment duration due to differences in personality traits may be "direct" through differences in individual search intensities but also "indirect" through sectoral choice which in turn reflects personality traits.

\section{Employment Spells}

In a second step of our empirical study, we also analyze the effect of personality traits on employment duration of the formerly unemployed in order to explore to what

\footnotetext{
${ }^{4}$ The detailed descriptive statistics of all variables used in our analysis are available as web appendix.
} 
extent the same personality traits contribute to employment stability. The sample of employment spells consists of 4191 observations from which $31 \%$ percent are right censored. The summary statistics of the employment durations and personality traits of this sample are given in Table A3. About $50 \%$ of the employment spells lasts at least one year. Table A3 provides information on the distribution of the covariates by occupational status and sectors in the current job. In fact, the comparison of averages of the covariates for the employed sample gives similar figures to that for the unemployed sample. This result is not really surprising given that individuals' occupational position and the sector in which they are working do not often change.

\section{Empirical Results}

For the empirical study, we use the approach proposed by Han \& Hausman (1990) for the analysis of grouped durations. This model is based on a semiparametric proportional hazard rate of the form

$$
\lambda_{i}(\tau)=\lim _{\Delta \rightarrow 0^{+}} \frac{\operatorname{Pr}\left[\tau<t_{i}<\tau+\Delta \mid t_{i}>\tau\right]}{\Delta}=\lambda_{0}(\tau) \exp \left(-X_{i}^{\prime} \beta\right)
$$

where $t_{i}$ is the unemployment duration (failure time), $\lambda_{0}(\cdot)$ the base line hazard and $X_{i}$ a vector of covariates. Integration and taking logs on both sides gives the log integrated baseline hazard:

$$
\Lambda_{0}(t)=\ln \int_{0}^{t} \lambda_{0}(\tau) d \tau=X_{i}^{\prime} \beta+\varepsilon_{i}
$$

where $\varepsilon_{i}=\ln \int_{0}^{t} \lambda_{i}(\tau) d \tau$ is extreme value distributed. Durations are grouped into $T$ subperiods. The subperiod $t$ refers to the time interval between consecutive time points $t-1$ and $t$. Thus, the probability of worker $i$ leaving the unemployment pool 
in this subperiod is:

$$
\begin{aligned}
\operatorname{Pr}\left[\text { leaving unemployment in subperiod } t \mid X_{i}\right] & =\int_{\Lambda_{0}(t-1)-X_{i}^{\prime} \beta}^{\Lambda_{0}(t)-X_{i}^{\prime} \beta} f(\varepsilon) d \varepsilon \\
& =F_{\varepsilon}\left(\Lambda_{0}(t)-X_{i}^{\prime} \beta\right)-F_{\varepsilon}\left(\Lambda_{0}(t-1)-X_{i}^{\prime} \beta\right),
\end{aligned}
$$

where $F_{\varepsilon}(\cdot)$ denotes the cdf of the extreme value distribution. Let the indicator variable $Y_{i t}$ be

$$
Y_{i t}= \begin{cases}1, & \text { if } i \text { exits unemployment in subperiod } t \\ 0, & \text { otherwise }\end{cases}
$$

With the use of this indicator variable we can write the likelihood function of $N$ observations:

$$
\begin{aligned}
& L\left(\beta, \Lambda_{0}(1), \ldots, \Lambda_{0}(T)\right) \\
= & \prod_{i=1}^{N} \prod_{t=1}^{T}\left\{F_{\varepsilon}\left(\Lambda_{0}(t)-X_{i}^{\prime} \beta\right)-F_{\varepsilon}\left(\Lambda_{0}(t-1)-X_{i}^{\prime} \beta\right)\right\}^{D_{i} Y_{i t}}\left\{1-F_{\varepsilon}\left(\Lambda_{0}(t)-X_{i}^{\prime} \beta\right)\right\}^{1-D_{i}},
\end{aligned}
$$

where $D_{i}$ is the censoring indicator taking on the value 1 , if duration $t_{i}$ has elapsed and 0 if there is right censoring. The likelihood takes on the form of an ordered response model with censoring. We follow the argumentation of Han \& Hausman (1990) and use the logit distribution to approximate the outcome probabilities of the extreme value distribution. The threshold parameters $\Lambda_{0}(1), \ldots, \Lambda_{0}(T)$, which are jointly estimated with the coefficients on the explanatory variables, serve as grid point estimates for the (continuous) log integrated hazard rate.

For our application, the Han-Hausman approach has several advantages. First, it is a well-suited model for monthly measured unemployment duration. Since we cannot 
assume that monthly measured unemployment duration is a continuous variable, we use a model for grouped duration. Second, this method has more flexibility than standard parametric proportional hazard specifications. In particular, its flexibility arises from the fact that we do not need to specify any functional form for the baseline hazard function. As Meyer (1990) argues, the semiparametric hazard estimation hinders inconsistent estimation of covariates due to a misspecified baseline hazard function.

The estimates for the determinants of unemployment duration based on the HanHausman estimator are given in Table A4 in Appendix. As defined by Equation (4.1), a positive coefficient indicates a negative effect of the corresponding covariate on the hazard rate and thus a positive effect on unemployment duration. We analyze these effects first for the overall sample. Then, considering the gender differences and possible differences for natives and immigrants, we estimate the model for these subsamples. Lastly, since the effects of the personality traits are context related, we analyze the effect of the Big Five separately by occupational status and sectors in the previous job. For this purpose, we create corresponding subsamples for blue collar and white collar workers, as well as for the largest sectors: manufacturing, construction and service. Regression results are given for the overall sample and also for the subsamples separated by gender, nationality, occupational status and sectors. For the regressions, we use the standardized indices for the Big Five traits. Thus, one unit change in one of the Big Five variables in the regression represents a change of one standard deviation of the same variable in levels. The observed unemployment spells are grouped in three monthly unemployment durations of 18 months and the last threshold is set in the 24th month, so that we obtain seven estimation points (thresholds) for the log integrated rate. ${ }^{5}$ Longer durations are

\footnotetext{
${ }^{5}$ We repeated the regression analysis with various numbers of threshold parameters. The results
} 
captured in a remaining group. The corresponding plot of hazard rates at the mean of the explanatory variables for the first regression is given in Figure B1. The hazard rate reveals a plausible shape by falling in the first six moth dramatically and falling furthermore until the unemployment benefit scheme forces the unemployed to increase search intensity.

Table 2: Summary of results for different subsamples of unemployed

\begin{tabular}{l|ccccc}
\hline \hline & CONSC & EXT & AGR & OPE & NEU \\
\hline Entire Sample & $8.23^{* * *}$ & - & - & $6.29^{* *}$ & $-7.85^{* * *}$ \\
\hline Female & - & - & - & $13.51^{* * *}$ & - \\
Male & $14.25^{* * *}$ & - & - & - & $-10.78^{* * *}$ \\
\hline German & $8.30^{* *}$ & - & - & - & $-7.23^{* * *}$ \\
Foreign & - & - & - & $34.88^{* * *}$ & - \\
\hline Blue Collar & $12.63^{* * *}$ & - & - & $8.80^{* *}$ & $-9.32^{* * *}$ \\
White Collar & - & - & - & - & $-11.01^{* *}$ \\
\hline Manufacturing & $13.66^{* *}$ & - & - & $16.85^{* *}$ & - \\
Construction & $24.94^{* * *}$ & - & - & - & - \\
Service & - & - & - & $13.75^{* *}$ & $-13.77^{* * *}$ \\
\hline \hline
\end{tabular}

Note: The numbers indicate the percentage change in the hazard rates with respect to one standard deviation increase in the measure of personality trait. *:\% 10 significance, ${ }^{* *}: \% 5$ significance, ${ }^{* * *}: \% 1$ significance.

We summarize the results related to the personality traits in Table 2. We only report the percentage change in the hazard rates with respect to one standard deviation increase in the measure of the personality trait, if the coefficient estimate of the corresponding personality trait is significant. We do not find any significant impact of Extraversion and Agreeableness on unemployment duration for the overall sample as well as for the subsamples. Note, however, that our estimates are conditional on the previous sector and occupation. Since sectoral and occupational choice is also determined by personality traits (e.g., more agreeable workers find themselves in the

of interest are not sensitive to the choice of the number of thresholds. 
service sector) our results simply indicate that no additional effect can be identified from the data. In terms of a structural model, there could be two compensating effects of Agreeableness on the unemployment duration. There is a well documented empirical result on the negative correlation between Agreeableness and wages, which could indicate lower reservation wage, but also lower wage offers in average. Since these two effects could balance each other, we do not see any significant effect on the duration of unemployment.

The signs of the effects of the three other personality traits, intraindividual traits, are consistent across subsamples provided they are significant. The three traits Conscientiousness, Openness and Neuroticism are significant for the estimates based on the overall sample. More conscientious and more open workers are more likely to find a new job faster, while Neuroticism is a trait that is likely to hinder job opportunities. Conscientious people are more likely to have lower search costs because they are more organized and more efficient searchers by definition. Therefore, they will receive more job offers on average than others. Moreover, they are also expected to give better signals to the potential employers which would mean higher wage offer and higher probability of accepting the offer. The net effect on the hazard rate will, therefore, be positive. Open people are expected to be less choosy in their job search and more likely to apply to a variety of jobs. This will increase the job arrival rate and the wage offers will also be distributed over a larger interval. It is also intuitive to think that the reservation wage of an open individual is lower because she values the experiences more. Thus, the positive net effect of this personality trait on the hazard rate coincides with our expectations. Neuroticism, on the other hand, may increase the search costs, as the neurotic people do not handle problematic situations well. This would lead to inefficient job search and negative signals to the potential employees. Hence, we observe that the hazard rate decreases with higher scores in 
Neuroticism.

The effect of Openness on unemployment duration is particularly pronounced for foreign workers. An increase of the Openness score by one standard deviation leads to an increase of the hazard rate by almost 35 percent. For labor markets with rather restrictive career patterns like the German one, where changes in the profession are comparatively rare and difficult due to legislative restrictions, Openness reflects a worker's ability to cope with new situations. In this sense, this trait is particularly valuable for foreign workers who, by definition, have to cope with the problem of a new working environment. A similar reasoning holds for female workers. For the German labor market, Franz et al. (2000) find that women, who have changed the job they have been trained for and who also changed employer, face significant earnings reductions. Thus, the trait Openness serves as a compensation and is therefore most valuable for persons who are more likely to face interruptions in their career and need to adjust to new working environments.

The finding that personality traits measured by the Big Five are more pronounced for blue collar workers compared to white collar workers is rather plausible because, for white collar workers, cognitive skills are more relevant than personality traits. Here, Conscientiousness, Openness positively affect the success of finding a job and Neuroticism negatively affects it. For white collar workers, only Neuroticism turns out to be a handicap for a successful job search. Our sector specific analysis clearly confirms that the relevance of certain personality traits is sector specific. Openness turns out to be a useful trait for those unemployed who had their previous job in the manufacturing or in the service sector. Neuroticism is a handicap for former employees of the service sector. For the construction sector and the service sector, we find a significant negative effect of Conscientiousness on the duration of unem- 
ployment.

The effects of the other explanatory variables, which are not related to personality traits, reveal the expected sign. Increase in educational attainment decreases the unemployment duration. Married people have shorter unemployment spells. Unemployment benefits increases the unemployment duration by reducing the search intensity. Having children creates a negative incentive effect for women while the effect is positive for males and, hence, a gender specific effect.

Our estimates reflect the conditional effects of personality traits on individual unemployment duration given the individual's educational choice. Personality traits may also have an effect on educational choices and educational success. Therefore, we also performed the same regression omitting the schooling variables. The results (see Web Appendix), however, did not change substantially so that we conclude that the indirect effects of personality traits through education are of minor importance.

Our findings that the effect of the personality traits are strongly context related are confirmed when looking at the employment spells of the formerly unemployed. The employment spells are also grouped in three monthly employment durations lasting 18 months. The corresponding plot of hazard rates at the mean of the explanatory variables for the employment duration regression is given Figure B1 of Appendix B. ${ }^{6}$ Here, the hazard rate of employment is low but increases over time, indicating a positive duration dependence going along with the increase of on-the-job experience. Contrary to the hazard rate for the unemployed, no dramatic changes can be observed which simply reflects the fact that, in employment, the incentive

\footnotetext{
${ }^{6}$ In order to make the unemployment and employment hazard rates comparable the same thresholds are used.
} 
scheme to exit does not change substantially.

Table 3: Summary of results for different subsamples of employed

\begin{tabular}{l|ccccc}
\hline \hline & CONSC & EXT & AGR & OPE & NEU \\
\hline Entire Sample & $-10.01^{* * *}$ & - & - & - & $9.26^{* * *}$ \\
\hline Female & $-9.23^{*}$ & - & - & $9.33^{*}$ & - \\
Male & $-9.90^{* *}$ & - & - & - & $10.74^{* *}$ \\
\hline German & $-7.42^{* *}$ & - & - & $6.95^{* *}$ & $11.35^{* * *}$ \\
Foreign & $-25.53^{* * *}$ & - & $24.58^{* *}$ & - & - \\
\hline Blue Collar & $-12.51^{* * *}$ & - & - & - & - \\
White Collar & - & - & - & - & $9.34^{*}$ \\
\hline Manufacturing & - & - & $29.41^{* * *}$ & $-14.34^{* *}$ & - \\
Construction & $-14.31^{* *}$ & - & - & - & - \\
Service & - & - & - & - & $15.73^{* * *}$ \\
\hline \hline
\end{tabular}

Note: The numbers indicate the percentage change in the hazard rates with respect to one standard deviation increase in the measure of personality trait. ${ }^{*}: \%$ 10 significance, ${ }^{* *}: \% 5$ significance, ${ }^{* * *}: \% 1$ significance.

The estimation results for the employment durations are shown in Table A5 in Appendix and Table 3 summarizes the significant estimates of personality trait measures for all subsamples of employed. Looking at the overall sample first, we see that, in principle, the signs of the coefficients simply change, i.e., traits useful for finding a job are the same as those useful for keeping the job. This holds in particular for Neuroticism for which we also find significant coefficients in most of the subsamples. For foreign workers, the relative importance of the traits switches. While Openness seems to be a decisive trait in finding a job, Conscientiousness is the one that guarantees job stability. At the same time, Agreeableness has a negative effect on the employment duration.

All in all, the power of the Big Five traits to explain employment duration is not as large as it is for unemployment durations. The results are confirmed when looking 
at the employment durations by job status or sectors separately. The effect of Conscientiousness on employment duration is positive for blue collar workers. Neuroticism is the only significant personality trait for white-collar workers. One standard deviation increase in Neuroticism results in an approximately $9 \%$ increase in unemployment hazard of white collar workers. In the manufacturing sector, Agreeableness has a negative effect on employment duration, whereas Openness has a positive effect. For those who are employed in the construction sector, the only personality trait which plays a role is Conscientiousness. Neuroticism is the only significant personality trait for employment in the service sector.

For the interpretation of our results we implicitly assume that personality traits are stable in adulthood. This assumption cannot be tested given our data limitations and would only be testable if personality traits are measured at different point over the life cycle. Our identifying assumption finds support by previous findings in the psychology literature. Although the stability of personality is still an open question for psychologists, there is significant literature supporting the stability of personality in the adulthood, especially if it is measured by underlying traits (see, for example, Heatherton \& Weinberger, 1994, for a review). More recent papers, such as Costa et al. (2000); Costa \& McCrae (2006) provide additional evidence regarding the stability of personality during the adulthood. Moreover, Costa et al. (2000) show that life events have very little effect on personality traits.

Using the same Big Five questions of the SOEP, Wichert \& Pohlmeier (2010) show for the case of female labor force participation, that personality traits measured in a cross-section have stable explanatory power. In addition, they regress the Big Five responses on indicators of the labor force participation in the past and find no evidence that the responses are effected by the work history. If an individual's 
personality traits change endogenously due to the employment (e.g. ceteris paribus a person without unemployment history is more open than somebody who was unemployed in previous years) we would find significant differences in the response behavior except in 2005 with respect to their previous employment history. Evidence against a reverse causality in the sense that the self-assessments are driven by the employment status is provided in Table 4 below. Here, we test the mean differences of the scores by employment status at the survey time in this particular year. Only for the trait Neuroticism, we find differences in response behavior according to employment status. For all other traits, there is clear evidence that employment and response behavior are uncorrelated. Additionally, we use the Kolmogorov-Smirnov test to test for equality of distribution functions. The large p-values indicate a clear non-rejection of the null that the distributions of the Big Five personality traits for individuals employed and unemployed in the survey year do not differ. Figure 2 illustrates the kernel density estimates of the traits by participation status at the time of interview. We see that the distribution of the personality traits are close to the normal distribution except the personality trait Conscientiousness, which is left skewed. The reason could be that the individuals tend to give more socially desirable answers to the questions related to the Conscientiousness. However, this is true for both employed and unemployed samples. Given these results, we can at least argue that the response behavior is not affected by employment status. 
Table 4: Mean and Distribution of the Big Five Traits by Employment Status in 2005

\begin{tabular}{l|cc|cc|c|c}
\hline \hline & \multicolumn{2}{|c|}{ Employed } & \multicolumn{2}{c|}{ Unemployed } & t-test & Kolmogorov-Smirnov \\
\hline & Mean Std. Dev. & Mean Std. Dev. & p-value & p-value \\
\hline Conscientiousness & 18.09 & 2.52 & 17.99 & 2.53 & 0.55 & 0.97 \\
Extraversion & 14.58 & 3.41 & 14.73 & 3.33 & 0.53 & 0.50 \\
Agreeableness & 16.22 & 2.88 & 16.27 & 2.87 & 0.82 & 0.79 \\
Openness & 13.45 & 3.51 & 13.35 & 3.43 & 0.66 & 0.76 \\
Neuroticism & 11.67 & 3.57 & 12.17 & 3.51 & 0.04 & 0.21 \\
\hline No. of obs. & \multicolumn{7}{|c|}{1001} & \multicolumn{7}{c|}{270} & & \\
\hline \hline
\end{tabular}

\section{Conclusion}

Our goal in this paper has been to examine the role of personality traits in determining the success of unemployed workers seeking a job and their success in keeping the subsequent job. This is done by estimating a reduced form unemployment duration model with the semiparametric proportional hazard rate method by Han \& Hausman (1990). We can show that personality traits are major determinants of job search behavior. Not all five dimensions of the Big Five contribute, however, to explaining observed individual unemployment durations in the same way. In fact, the traits Extraversion and Agreeableness reveal no explanatory power while the relevance of the other three traits vary across subgroups.

We find strong evidence that the role of the Big Five traits is context-related. The traits do seem to matter more if a person is unemployed. It appears that low scores for Neuroticism and high scores for Conscientiousness are important determinants for being offered and holding down a job. The relevance of personality traits in explaining individual job search behavior is also confirmed by focusing on the effects across different occupations and sectors. In this sense our study complements 
previous studies on the effects of noncognitive skills on educational attainment and earnings by showing that personality traits are also quantitatively important factors for reducing individual unemployment and increasing job stability.

We provide some explorative evidence that the problem of reverse causality is primarily theoretical in nature. Nevertheless, a more elaborate duration analysis based on panel data with multiple measurements of the personality traits at different points in time could tackle the endogeneity problem in taking greater care of this detail. A factor analytic approach could deal with the soft nature of self-assessed personality traits in a more sophisticated fashion.

Our results contribute to the discussion on individual heterogeneity in duration models by showing that observable differences in personalities are able to explain parts of individual differences in job search behavior. This indicates that appropriate screening of the unemployed by assessing their personalities and eventually offering appropriate interventions (e.g. training of self-regulatory skills) may improve their success in the labor market.

Future research should focus on the channels though which personality traits affect the chances of finding a job. A structural approach able to identify to what extend personality traits serve as signals for a potential employer and to what extend they simply increase the job search effort would be desirable. Empirical estimates of such a structural approach would help to evaluate the role of specific training programs (e.g. application training) for the unemployed. 


\section{References}

Anand, P., Hunter, G., Carter, I., Dowding, K., Guala, F., \& Van Hees, M. (1991). The development of capability indicators. Journal of Human Development and Capabilities: A Multi-Disciplinary Journal for People-Centered Development, 10, $125-152$.

Barrick, M. B., \& Mount, M. K. (1991). The big five personality dimensions and job performance: A meta-analysis. Personnel Psychology, 44, 1-26.

Borghans, L., Duckworth, A. L., Heckman, J. J., \& Weel, B. t. (2008). The Economics and Psychology of Personality Traits. Journal Human Resources, 43, 972-1059.

Bowles, S., Gintis, H., \& Osborne, M. (2001). Incentive-enhancing preferences: Personality, behavior, and earnings. The American Economic Review, 91, 155158.

Boyce, C. J. (2010). Understanding fixed effects in human well-being. Journal of Economic Psychology, 31, $1-16$.

Carneiro, P., \& Heckman, J. J. (2004). Human capital policy. In J. J. Heckman, A. B. Krueger, \& B. M. Friedman (Eds.), Inequality in America: What Role for Human Capital Policy? (pp. 77-240). Cambridge, Mass.: The MIT press.

Costa, P. T., Herbst, J. H., McCrae, R. R., \& Siegler, I. C. (2000). Personality at midlife: Stability, intrinsic maturation, and response to life events. Assessment, 7 .

Costa, P. T., \& McCrae, R. R. (1988). Personality in adulthood: A six-year longitudinal study of self-reports and spouse ratings on the neo personality inventory. Journal of Personality and Social Psychology, 54, 853863.

Costa, P. T., \& McCrae, R. R. (2006). Age changes in personality and their origins: Comment on Roberts, Walton, and Viechtbauer (2006). Psychological Bulletin, 132.

Cronbach, L. (1951). Coefficient alpha and the internal structure of tests. Psychometrika, 16, 297-334. 
Dehne, M., \& Schupp, J. (2007). Persnlichkeitsmerkmale im sozio-oekonomischen panel (soep) konzept, umsetzung und empirische eigenschaften. Research Notes No. 26, DIWBerlin.

Farkas, G. (2003). Cognitive skills and noncognitive traits and behaviors in stratification processes. Annual Review of Sociology, 29, 541 - 562.

Franz, W., Inkmann, J., Pohlmeier, W., \& Zimmermann, V. (2000). Young and out in germany: On youths' chances of labor market entrance in germany. In D. G. Blanchflower, \& R. B. Freeman (Eds.), Youth Employment and Joblessness in Advanced Countries chapter 10. (pp. 381 - 425). Chicago: University of Chicago Press.

Gerlitz, J.-Y., \& Schupp, J. (2005). Zur erhebung der big-five-basierten persnlichkeitsmerkmale im soep. Research Notes No. 4, DIWBerlin.

Han, A., \& Hausman, J. A. (1990). Flexible parametric estimation of duration and competing risk models. Journal of Applied Econometrics, 5, 1-28.

Heatherton, T. F., \& Weinberger, J. L. (1994). Can Personality Change?. American Psychological Association, Washington, DC.

Heckman, J. J., Stixrud, J., \& Urzua, S. (2006). The effects of cognitive and noncognitive abilities on labor market outcomes and social behavior. Journal of Labor Economics, 24, $411-482$.

Heineck, G., \& Anger, S. (2010). The returns to cognitive abilities and personality traits in germany. Labour Economics, 17, 535 - 546.

John, O., \& Srivastava, S. (1999). The big five trait taxonomy: history, measurement, and theoretical perspectives. In L. Pervin, \& O. John (Eds.), Handbook of Personality: Theory and Research (p. 102138). New York: Guilford.

McCrae, R. R., \& Costa, P. T. (1994). The stability of personality: Observations and evaluations. Current Directions in Psychological Science, 3, 173 - 177.

Meyer, B. D. (1990). Unemployment insurance and unemployment spells. Econometrica, 58, 757-782.

Mohanty, M. S. (2009). Effects of positive attitude on earnings: Evidence from the us longitudinal data. Journal of Socio-Economics, 38, 357-371. 
Mohanty, M. S. (2010). Effects of positive attitude and optimism on employment: Evidence from the us data. Journal of Socio-Economics, 39, 258-270.

Mortensen, D. T., \& Pissarides, C. A. (1999). New develpoments in models of search in the labor market. In O. Ashenfelter, \& D. Card (Eds.), Handbook of Labor Economics, Vol. $3 b$ (p. 2567 2627). Amsterdam: Elsevier.

Mueller, G., \& Plug, E. (2006). Estimating the effect of personality on male-female earnings. Industrial and Labor Relations Review, 60, 3-22.

Norman, W. T. (1963). Toward an adequate taxonomy of personality attributes: Replicated factor structure in peer nomination personality ratings. Journal of Abnormal and Social Psychology, 66, 574-583.

Nyhus, E., \& Pons, E. (2005). The effects of personality on earnings. Journal of Economic Psychology, 26, 363-384.

Ozer, D. J., \& Benet-Martnez, V. (2006). Personality and the prediction of consequential outcomes. Annual Review of Psychology, 57, 401-421.

Pissarides, C. A. (2000). Equilibrium unemployment theory. (2nd ed.). Cambridge, Mass.: MIT Press.

Schmit, M. J., Amel, E. L., \& Ryan, A. M. (1993). Self-reported assertive job-seeking behaviors of minimally educated job hunters. Personnel Psychology, 46, 105-124.

Srivastava, S., John, O. P., Gosling, S. D., \& Potter, J. (2003). Development of personality in early and middle adulthood: Set like plaster or persistent change? ournal of Personality and Social Psychology, 84, 1041-1053.

Tokar, D. M., Fischer, A. R., \& Subich, L. M. (1998). Personality and vocational behavior: A selective review of the literature, 1993-1997. Journal of Vocational Behavior, 53, 115-153.

Uysal, S. D., \& Pohlmeier, W. (2010). Web appendix: Unemployment duration and personality. http://econometrics.wiwi.uni-konstanz.de/prof/pdf/working paper/webappendix.pdf.

Wichert, L., \& Pohlmeier, W. (2010). Female labor force participation and the big five. Centre for European Economic Research (ZEW), Mannheim, Discussion Paper No. 10-003. 
Zetterberg, J. (2005). Swedish evidence on the impact of cognitive and non-cognitive ability on earnings - an extended pre-market factor approach. Institute for Labour Market Policy Evaluation. 


\section{Appendix A. Tables}

Table A1: Definition of Variables

\begin{tabular}{|c|c|}
\hline Variable & Definition \\
\hline DUR_UNEMP & Unemployment duration in months \\
\hline DUR_EMP & Employment duration in months \\
\hline LOW_EDU & Dummy, 1 if no degree or less than or equal to 10 years of schooling \\
\hline MID_EDU & Dummy, 1 if high school degree (12 or 13 years of schooling) or professional degree \\
\hline HIGH_VOC & Dummy, 1 if high school degree and vocational training \\
\hline HIGH_EDU & Dummy, 1 if highest degree is university degree \\
\hline FEMALE & Dummy, 1 if female \\
\hline GERMAN & Dummy, 1 if German \\
\hline GERMAN & Dummy, 1 if living in East Germany \\
\hline AGE & Age in years at the beginning of the unemployment spell \\
\hline MARR & Dummy, 1 if married at the beginning of the unemployment spell \\
\hline NOKID & Dummy, 1 if individual does not have children \\
\hline ONEKID & Dummy, 1 if women has one child \\
\hline TWOKID & Dummy, 1 if women has two children \\
\hline THREEKID & Dummy, 1 if women has three or more children \\
\hline ANYHELP & Dummy, 1 if worker received unemployment benefit \\
\hline & or relief during unemployment spell \\
\hline LNWAGE & Log of average hourly wages during employment spell \\
\hline \multicolumn{2}{|c|}{ Industry Dummy Variables } \\
\hline AGRI & $=1$ if in mining or agriculture \\
\hline MANU & $=1$ if in manufacturing \\
\hline TRANS & $=1$ if in transportation or public utilities \\
\hline CONSTRUC & $=1$ if in construction sector \\
\hline TRADE & $=1$ if in retail trade or wholesale \\
\hline SERVICE & $=1$ if in services \\
\hline \multicolumn{2}{|c|}{ Occupation Dummy Variables } \\
\hline APPREN & $=1$ if apprentice, trainee or intern \\
\hline SELF_EMP & $=1$ if self employed \\
\hline WORKER & $=1$ if worker \\
\hline EMPLOYEE & $=1$ if employee \\
\hline CIVIL & $=1$ if civil cervant \\
\hline AGRI_WORKER & $=1$ if agricultural worker \\
\hline \multicolumn{2}{|l|}{ Personality Traits } \\
\hline EXT & Score for Extraversion (from 3 to 21 (very pronounced)) \\
\hline AGR & Score for Agreeableness (from 3 to 21 (very pronounced)) \\
\hline CONSC & Score for Conscientiousness (from 3 to 21 (very pronounced)) \\
\hline NEU & Score for Neuroticism (from 3 to 21 (very pronounced)) \\
\hline OPE & Score for Openness to Experience (from 3 to 21 (very pronounced)) \\
\hline
\end{tabular}


Table A2: Summary Statistics of Unemployment Duration and Personality Measures for the Unemployed Sample

\begin{tabular}{l|c|cc|cc|cc|ccc}
\hline \hline & Entire Sample & \multicolumn{2}{|c|}{ By Gender } & \multicolumn{2}{c|}{ By Nationality } & \multicolumn{2}{c|}{ By Occupation } & \multicolumn{3}{c}{ By Sector } \\
& & Female & Male & German & Foreign & Blue-Col. & White-Col. & Manufact. Construct. Service \\
\hline DUR_UNEMP & 7.81 & 8.30 & 7.45 & 7.52 & 9.66 & 8.24 & 7.36 & 8.64 & 6.72 & 7.92 \\
& $(9.36)$ & $(9.23)$ & $(9.44)$ & $(8.95)$ & $(11.43)$ & $(10.17)$ & $(8.53)$ & $(10.56)$ & $(8.78)$ & $(8.92)$ \\
CONS & 18.00 & 18.20 & 17.86 & 18.00 & 17.99 & 18.11 & 18.00 & 18.10 & 17.94 & 17.91 \\
& $(2.65)$ & $(2.52)$ & $(2.74)$ & $(2.63)$ & $(2.78)$ & $(2.71)$ & $(2.49)$ & $(2.76)$ & $(2.76)$ & $(2.58)$ \\
EXT & 14.58 & 15.07 & 14.22 & 14.65 & 14.13 & 14.24 & 15.00 & 14.33 & 14.21 & 14.80 \\
& $(3.37)$ & $(3.32)$ & $(3.36)$ & $(3.34)$ & $(3.52)$ & $(3.39)$ & $(3.22)$ & $(3.44)$ & $(3.19)$ & $(3.46)$ \\
AGR & 16.16 & 16.74 & 15.73 & 16.12 & 16.37 & 15.94 & 16.41 & 16.34 & 15.45 & 16.38 \\
& $(2.92)$ & $(2.82)$ & $(2.92)$ & $(2.92)$ & $(2.96)$ & $(3.02)$ & $(2.80)$ & $(2.93)$ & $(3.00)$ & $(2.88)$ \\
OPE & 13.41 & 13.87 & 13.07 & 13.56 & 12.43 & 12.76 & 14.14 & 12.88 & 13.06 & 13.96 \\
& $(3.54)$ & $(3.48)$ & $(3.55)$ & $(3.49)$ & $(3.68)$ & $(3.55)$ & $(3.36)$ & $(3.60)$ & $(3.56)$ & $(3.54)$ \\
NEU & 12.21 & 12.70 & 11.85 & 12.19 & 12.35 & 12.37 & 12.04 & 12.12 & 12.10 & 12.37 \\
& $(3.57)$ & $(3.59)$ & $(3.52)$ & $(3.56)$ & $(3.62)$ & $(3.53)$ & $(3.63)$ & $(3.47)$ & $(3.36)$ & $(3.69)$ \\
\hline$\sharp$ of obs. & 4466 & 1886 & 2580 & 3853 & 613 & 2323 & 1549 & 1065 & 820 & 1536 \\
\hline \hline
\end{tabular}

Standard errors are given in parentheses.

Table A3: Summary Statistics of Employment Duration and Personality Measures for the Employed Sample

\begin{tabular}{l|c|cc|cc|cc|ccc}
\hline \hline \multirow{2}{*}{ Entire Sample } & \multicolumn{2}{|c|}{ By Gender } & \multicolumn{2}{c|}{ By Nationality } & \multicolumn{2}{c|}{ By Occupation } & \multicolumn{3}{c}{ By Sector } \\
& & Female & Male & German & Foreign & Blue-Col. & White-Col. & Manufact. & Construct. Service \\
\hline \multirow{4}{*}{ CONSC } & 33.36 & 29.77 & 36.04 & 32.57 & 38.41 & 30.60 & 37.89 & 42.22 & 25.04 & 31.56 \\
& $(44.43)$ & $(39.12)$ & $(47.85)$ & $(43.34)$ & $(50.62)$ & $(42.69)$ & $(46.29)$ & $(52.50)$ & $(34.68)$ & $(42.35)$ \\
EXT & 18.00 & 18.22 & 17.84 & 18.00 & 18.01 & 18.08 & 18.00 & 18.06 & 17.94 & 17.93 \\
& $(2.65)$ & $(2.50)$ & $(2.75)$ & $(2.63)$ & $(2.79)$ & $(2.73)$ & $(2.50)$ & $(2.74)$ & $(2.79)$ & $(2.59)$ \\
AGR & 14.60 & 15.10 & 14.23 & 14.68 & 14.10 & 14.24 & 14.92 & 14.35 & 14.17 & 14.88 \\
& $(3.39)$ & $(3.33)$ & $(3.38)$ & $(3.36)$ & $(3.54)$ & $(3.38)$ & $(3.30)$ & $(3.50)$ & $(3.09)$ & $(3.44)$ \\
OPE & 16.17 & 16.77 & 15.72 & 16.14 & 16.35 & 15.91 & 16.52 & 16.23 & 15.38 & 16.47 \\
& $(2.92)$ & $(2.80)$ & $(2.93)$ & $(2.91)$ & $(2.99)$ & $(3.03)$ & $(2.77)$ & $(2.96)$ & $(3.00)$ & $(2.86)$ \\
NEU & 13.43 & 13.93 & 13.06 & 13.60 & 12.39 & 12.75 & 14.04 & 12.97 & 13.02 & 13.96 \\
& $(3.54)$ & $(3.48)$ & $(3.53)$ & $(3.48)$ & $(3.71)$ & $(3.48)$ & $(3.37)$ & $(3.55)$ & $(3.55)$ & $(3.49)$ \\
& 12.18 & 12.68 & 11.79 & 12.16 & 12.30 & 12.40 & 12.02 & 12.04 & 12.10 & 12.20 \\
$\#$ of obs. & $(3.58)$ & $(3.62)$ & $(3.50)$ & $(3.57)$ & $(3.65)$ & $(3.49)$ & $(3.67)$ & $(3.54)$ & $(3.31)$ & $(3.62)$ \\
\hline \hline
\end{tabular}

Standard errors are given in parentheses. 
Table A4: Regression Results for Unemployment Durations

\begin{tabular}{|c|c|c|c|c|c|c|c|c|c|c|}
\hline & \multirow[t]{2}{*}{ Entire Sample } & \multicolumn{2}{|c|}{ By Gender } & \multicolumn{2}{|c|}{ By Nationality } & \multicolumn{2}{|c|}{ By Occupation } & \multicolumn{3}{|c|}{ By Sector } \\
\hline & & Female & Male & German & Foreign & Blue-Col. & White-Col. & Manufact. & Construct. & Service \\
\hline \multicolumn{11}{|l|}{ Personality Traits } \\
\hline \begin{tabular}{l|l} 
CONSCST &
\end{tabular} & $\begin{array}{l}-0.079 \\
(0.01)\end{array}$ & $\begin{array}{l}-0.002 \\
(0.96)\end{array}$ & $\begin{array}{l}-0.133 \\
(0.00)\end{array}$ & $\begin{array}{l}-0.080 \\
(0.02)\end{array}$ & $\begin{array}{l}-0.068 \\
(0.44)\end{array}$ & $\begin{array}{l}-0.119 \\
(0.01)\end{array}$ & $\begin{array}{l}-0.020 \\
(0.70)\end{array}$ & $\begin{array}{l}-0.128 \\
(0.05)\end{array}$ & $\begin{array}{l}-0.223 \\
(0.01)\end{array}$ & $\begin{array}{l}-0.043 \\
(0.43)\end{array}$ \\
\hline EXTST & $\begin{array}{l}0.015 \\
(0.64)\end{array}$ & $\begin{array}{l}0.003 \\
(0.96)\end{array}$ & $\begin{array}{l}0.020 \\
(0.63)\end{array}$ & $\begin{array}{l}0.004 \\
(0.90)\end{array}$ & $\begin{array}{l}0.106 \\
(0.19)\end{array}$ & $\begin{array}{l}0.045 \\
(0.29)\end{array}$ & $\begin{array}{l}-0.008 \\
(0.88)\end{array}$ & $\begin{array}{l}-0.012 \\
(0.85)\end{array}$ & $\begin{array}{l}-0.015 \\
(0.84)\end{array}$ & $\begin{array}{l}0.060 \\
(0.27)\end{array}$ \\
\hline AGRST & $\begin{array}{l}0.017 \\
(0.59)\end{array}$ & $\begin{array}{l}-0.011 \\
(0.81)\end{array}$ & $\begin{array}{l}0.028 \\
(0.50)\end{array}$ & $\begin{array}{l}0.002 \\
(0.96)\end{array}$ & $\begin{array}{l}0.085 \\
(0.34)\end{array}$ & $\begin{array}{l}0.059 \\
(0.17)\end{array}$ & $\begin{array}{l}-0.007 \\
(0.90)\end{array}$ & $\begin{array}{l}0.065 \\
(0.32)\end{array}$ & $\begin{array}{l}0.052 \\
(0.50)\end{array}$ & $\begin{array}{l}0.014 \\
(0.79)\end{array}$ \\
\hline OPEST & $\begin{array}{r}-0.061 \\
(0.05)\end{array}$ & $\begin{array}{l}-0.127 \\
(0.01)\end{array}$ & $\begin{array}{l}-0.020 \\
(0.63)\end{array}$ & $\begin{array}{l}-0.028 \\
(0.41)\end{array}$ & $\begin{array}{l}-0.299 \\
(0.00)\end{array}$ & $\begin{array}{l}-0.084 \\
(0.05)\end{array}$ & $\begin{array}{l}-0.011 \\
(0.84)\end{array}$ & $\begin{array}{r}-0.156 \\
(0.02)\end{array}$ & $\begin{array}{l}0.038 \\
(0.61)\end{array}$ & $\begin{array}{l}-0.129 \\
(0.02)\end{array}$ \\
\hline NEUST & $\begin{array}{r}0.082 \\
(0.00) \\
\end{array}$ & $\begin{array}{l}0.058 \\
(0.18) \\
\end{array}$ & $\begin{array}{l}0.114 \\
(0.00) \\
\end{array}$ & $\begin{array}{l}0.075 \\
(0.02) \\
\end{array}$ & $\begin{array}{l}0.084 \\
(0.28) \\
\end{array}$ & $\begin{array}{l}0.098 \\
(0.01) \\
\end{array}$ & $\begin{array}{l}0.117 \\
(0.02) \\
\end{array}$ & $\begin{array}{l}0.061 \\
(0.31) \\
\end{array}$ & $\begin{array}{l}0.056 \\
(0.43) \\
\end{array}$ & $\begin{array}{l}0.148 \\
(0.00) \\
\end{array}$ \\
\hline \multicolumn{11}{|c|}{ Other Characteristics } \\
\hline \begin{tabular}{l|l}
$\mathrm{AGE}$ & \\
\end{tabular} & $\begin{array}{l}0.026 \\
(0.00)\end{array}$ & $\begin{array}{l}0.031 \\
(0.00)\end{array}$ & $\begin{array}{l}0.020 \\
(0.00)\end{array}$ & $\begin{array}{l}0.032 \\
(0.00)\end{array}$ & $\begin{array}{l}-0.003 \\
(0.74)\end{array}$ & $\begin{array}{l}0.015 \\
(0.00)\end{array}$ & $\begin{array}{l}0.041 \\
(0.00)\end{array}$ & $\begin{array}{l}0.031 \\
(0.00)\end{array}$ & $\begin{array}{l}0.011 \\
(0.16)\end{array}$ & $\begin{array}{l}0.032 \\
(0.00)\end{array}$ \\
\hline GENDER & $\begin{array}{l}0.291 \\
(0.00)\end{array}$ & & & $\begin{array}{l}0.302 \\
(0.00)\end{array}$ & $\begin{array}{l}0.443 \\
(0.02)\end{array}$ & $\begin{array}{l}0.411 \\
(0.00)\end{array}$ & $\begin{array}{l}0.193 \\
(0.08)\end{array}$ & $\begin{array}{l}0.305 \\
(0.02)\end{array}$ & $\begin{array}{l}1.144 \\
(0.00)\end{array}$ & $\begin{array}{l}0.039 \\
(0.72)\end{array}$ \\
\hline GERMAN & $\begin{array}{l}-0.312 \\
(0.00)\end{array}$ & $\begin{array}{l}-0.459 \\
(0.00)\end{array}$ & $\begin{array}{c}-0.244 \\
(0.04)\end{array}$ & & & $\begin{array}{l}-0.221 \\
(0.05)\end{array}$ & $\begin{array}{l}-0.583 \\
(0.00)\end{array}$ & $\begin{array}{l}-0.148 \\
(0.34)\end{array}$ & $\begin{array}{l}-0.359 \\
(0.14)\end{array}$ & $\begin{array}{l}-0.441 \\
(0.01)\end{array}$ \\
\hline EAST & $\begin{array}{l}0.155 \\
(0.02)\end{array}$ & $\begin{array}{l}0.208 \\
(0.00)\end{array}$ & $\begin{array}{l}0.101 \\
(0.25)\end{array}$ & $\begin{array}{l}0.175 \\
(0.01)\end{array}$ & $\begin{array}{l}-0.072 \\
(0.86)\end{array}$ & $\begin{array}{l}0.213 \\
(0.02)\end{array}$ & $\begin{array}{l}0.188 \\
(0.07)\end{array}$ & $\begin{array}{l}-0.001 \\
(0.99)\end{array}$ & $\begin{array}{l}0.309 \\
(0.05)\end{array}$ & $\begin{array}{l}0.251 \\
(0.02)\end{array}$ \\
\hline MID_EDU & $\begin{array}{l}-0.461 \\
(0.00)\end{array}$ & $\begin{array}{l}-0.343 \\
(0.30)\end{array}$ & $\begin{array}{l}-0.500 \\
(0.00)\end{array}$ & $\begin{array}{l}-0.467 \\
(0.00)\end{array}$ & $\begin{array}{l}-0.443 \\
(0.01)\end{array}$ & $\begin{array}{l}-0.517 \\
(0.00)\end{array}$ & $\begin{array}{l}0.137 \\
(0.61)\end{array}$ & $\begin{array}{l}-0.643 \\
(0.00)\end{array}$ & $\begin{array}{l}-0.171 \\
(0.47)\end{array}$ & $\begin{array}{l}-0.433 \\
(0.01)\end{array}$ \\
\hline HIGH_VOC & $\begin{array}{l}-0.628 \\
(0.00)\end{array}$ & $\begin{array}{l}-0.487 \\
(0.76)\end{array}$ & $\begin{array}{l}-0.721 \\
(0.00)\end{array}$ & $\begin{array}{l}-0.688 \\
(0.00)\end{array}$ & $\begin{array}{l}0.119 \\
(0.80)\end{array}$ & $\begin{array}{l}-0.440 \\
(0.14)\end{array}$ & $\begin{array}{l}0.035 \\
(0.91)\end{array}$ & $\begin{array}{l}-0.911 \\
(0.02)\end{array}$ & $\begin{array}{l}0.358 \\
(0.59)\end{array}$ & $\begin{array}{l}-0.756 \\
(0.00)\end{array}$ \\
\hline HIGH_EDU & $\begin{array}{l}-0.640 \\
(0.00)\end{array}$ & $\begin{array}{l}-0.356 \\
(0.23)\end{array}$ & $\begin{array}{l}-0.852 \\
(0.00)\end{array}$ & $\begin{array}{l}-0.689 \\
(0.00)\end{array}$ & $\begin{array}{l}-0.332 \\
(0.31)\end{array}$ & $\begin{array}{c}-0.799 \\
(0.00)\end{array}$ & $\begin{array}{l}0.016 \\
(0.95)\end{array}$ & $\begin{array}{l}-0.757 \\
(0.00)\end{array}$ & $\begin{array}{l}-0.115 \\
(0.75)\end{array}$ & $\begin{array}{l}-0.737 \\
(0.00)\end{array}$ \\
\hline MARR & $\begin{array}{l}-0.138 \\
(0.05)\end{array}$ & $\begin{array}{c}-0.044 \\
(0.99)\end{array}$ & $\begin{array}{c}-0.149 \\
(0.14)\end{array}$ & $\begin{array}{l}-0.173 \\
(0.02)\end{array}$ & $\begin{array}{l}-0.037 \\
(0.86)\end{array}$ & $\begin{array}{r}-0.100 \\
(0.32)\end{array}$ & $\begin{array}{l}-0.151 \\
(0.20)\end{array}$ & $\begin{array}{r}-0.130 \\
(0.39)\end{array}$ & $\begin{array}{c}-0.198 \\
(0.30)\end{array}$ & $\begin{array}{c}-0.029 \\
(0.80)\end{array}$ \\
\hline ONEKID & $\begin{array}{l}-0.045 \\
(0.58)\end{array}$ & $\begin{array}{l}0.272 \\
(0.01)\end{array}$ & $\begin{array}{l}-0.296 \\
(0.01)\end{array}$ & $\begin{array}{l}-0.078 \\
(0.36)\end{array}$ & $\begin{array}{l}0.137 \\
(0.59)\end{array}$ & $\begin{array}{l}-0.069 \\
(0.53)\end{array}$ & $\begin{array}{l}-0.095 \\
(0.50)\end{array}$ & $\begin{array}{r}-0.350 \\
(0.03)\end{array}$ & $\begin{array}{c}-0.023 \\
(0.91)\end{array}$ & $\begin{array}{l}0.078 \\
(0.57)\end{array}$ \\
\hline TWOKID & $\begin{array}{l}-0.021 \\
(0.80)\end{array}$ & $\begin{array}{l}0.126 \\
(0.17)\end{array}$ & $\begin{array}{l}-0.201 \\
(0.08)\end{array}$ & $\begin{array}{l}-0.089 \\
(0.34)\end{array}$ & $\begin{array}{l}0.295 \\
(0.20)\end{array}$ & $\begin{array}{l}-0.083 \\
(0.48)\end{array}$ & $\begin{array}{l}0.008 \\
(0.95)\end{array}$ & $\begin{array}{l}-0.320 \\
(0.06)\end{array}$ & $\begin{array}{l}-0.043 \\
(0.84)\end{array}$ & $\begin{array}{l}0.051 \\
(0.73)\end{array}$ \\
\hline THREEKID & $\begin{array}{l}0.229 \\
(0.04)\end{array}$ & $\begin{array}{l}0.158 \\
(0.30)\end{array}$ & $\begin{array}{l}0.242 \\
(0.12)\end{array}$ & $\begin{array}{l}0.240 \\
(0.06)\end{array}$ & $\begin{array}{l}0.187 \\
(0.45)\end{array}$ & $\begin{array}{c}0.199 \\
(0.17)\end{array}$ & $\begin{array}{l}0.137 \\
(0.49)\end{array}$ & $\begin{array}{c}-0.110 \\
(0.64)\end{array}$ & $\begin{array}{c}0.740 \\
(0.01)\end{array}$ & $\begin{array}{l}0.249 \\
(0.18)\end{array}$ \\
\hline ANYHELP & $\begin{array}{l}0.861 \\
(0.00)\end{array}$ & $\begin{array}{l}1.091 \\
(0.00)\end{array}$ & $\begin{array}{l}0.663 \\
(0.00)\end{array}$ & $\begin{array}{l}0.863 \\
(0.00)\end{array}$ & $\begin{array}{l}0.937 \\
(0.00)\end{array}$ & $\begin{array}{c}0.707 \\
(0.00)\end{array}$ & $\begin{array}{l}0.991 \\
(0.00)\end{array}$ & $\begin{array}{l}0.908 \\
(0.00)\end{array}$ & $\begin{array}{l}0.525 \\
(0.04)\end{array}$ & $\begin{array}{l}0.762 \\
(0.00)\end{array}$ \\
\hline AGRI & $\begin{array}{l}-0.412 \\
(0.01)\end{array}$ & $\begin{array}{l}-0.128 \\
(0.97)\end{array}$ & $\begin{array}{c}-0.637 \\
(0.00)\end{array}$ & $\begin{array}{l}-0.480 \\
(0.00)\end{array}$ & $\begin{array}{l}0.203 \\
(0.70)\end{array}$ & $\begin{array}{l}-0.587 \\
(0.00)\end{array}$ & $\begin{array}{l}-0.057 \\
(0.89)\end{array}$ & & & \\
\hline MANU & $\begin{array}{l}0.016 \\
(0.84)\end{array}$ & $\begin{array}{l}0.016 \\
(0.56)\end{array}$ & $\begin{array}{l}-0.070 \\
(0.54)\end{array}$ & $\begin{array}{l}0.070 \\
(0.43)\end{array}$ & $\begin{array}{l}-0.205 \\
(0.33)\end{array}$ & $\begin{array}{c}-0.102 \\
(0.39)\end{array}$ & $\begin{array}{l}0.022 \\
(0.87)\end{array}$ & & & \\
\hline TRANS & $\begin{array}{l}-0.219 \\
(0.12)\end{array}$ & $\begin{array}{l}-0.259 \\
(0.22)\end{array}$ & $\begin{array}{l}-0.333 \\
(0.06)\end{array}$ & $\begin{array}{l}-0.175 \\
(0.26)\end{array}$ & $\begin{array}{l}-0.583 \\
(0.09)\end{array}$ & $\begin{array}{c}-0.244 \\
(0.20)\end{array}$ & $\begin{array}{l}-0.185 \\
(0.49)\end{array}$ & & & \\
\hline CONSTRUC & $\begin{array}{l}-0.406 \\
(0.00)\end{array}$ & $\begin{array}{l}0.453 \\
(0.04)\end{array}$ & $\begin{array}{c}-0.539 \\
(0.00)\end{array}$ & $\begin{array}{l}-0.391 \\
(0.00)\end{array}$ & $\begin{array}{l}-0.593 \\
(0.03)\end{array}$ & $\begin{array}{l}-0.575 \\
(0.00)\end{array}$ & $\begin{array}{l}0.201 \\
(0.33)\end{array}$ & & & \\
\hline TRADE & $\begin{array}{l}0.026 \\
(0.77)\end{array}$ & $\begin{array}{l}0.085 \\
(0.48)\end{array}$ & $\begin{array}{r}-0.099 \\
(0.48)\end{array}$ & $\begin{array}{l}0.047 \\
(0.61)\end{array}$ & $\begin{array}{l}-0.212 \\
(0.48)\end{array}$ & $\begin{array}{c}-0.124 \\
(0.41)\end{array}$ & $\begin{array}{l}0.065 \\
(0.60)\end{array}$ & & & \\
\hline APPREN & $\begin{array}{c}0.315 \\
(0.00)\end{array}$ & $\begin{array}{l}0.540 \\
(0.00)\end{array}$ & $\begin{array}{l}0.060 \\
(0.72)\end{array}$ & $\begin{array}{l}0.351 \\
(0.00)\end{array}$ & $\begin{array}{l}0.129 \\
(0.76)\end{array}$ & & & & & \\
\hline SELF_EMP & $\begin{array}{l}0.382 \\
(0.01)\end{array}$ & $\begin{array}{l}0.112 \\
(0.90)\end{array}$ & $\begin{array}{l}0.418 \\
(0.04)\end{array}$ & $\begin{array}{l}0.365 \\
(0.03)\end{array}$ & $\begin{array}{l}0.593 \\
(0.24)\end{array}$ & & & & & \\
\hline BLUE & $\begin{array}{c}0.105 \\
(0.16)\end{array}$ & $\begin{array}{l}0.342 \\
(0.00)\end{array}$ & $\begin{array}{c}-0.031 \\
(0.79)\end{array}$ & $\begin{array}{l}0.120 \\
(0.13)\end{array}$ & $\begin{array}{l}0.021 \\
(0.93)\end{array}$ & & & & & \\
\hline CIVIL & $\begin{array}{r}-0.601 \\
(0.09)\end{array}$ & $\begin{array}{l}-0.873 \\
(0.05)\end{array}$ & $\begin{array}{c}-0.594 \\
(0.20)\end{array}$ & $\begin{array}{l}-0.627 \\
(0.09)\end{array}$ & $\begin{array}{l}0.339 \\
(0.82)\end{array}$ & & & & & \\
\hline AGRI_WORKER & $\begin{array}{c}0.939 \\
(0.06)\end{array}$ & $\begin{array}{l}1.765 \\
(0.05)\end{array}$ & $\begin{array}{c}-0.100 \\
(0.89)\end{array}$ & $\begin{array}{l}0.939 \\
(0.07)\end{array}$ & $\begin{array}{l}1.577 \\
(0.32)\end{array}$ & & & & & \\
\hline Other Controls* & + & + & + & + & + & + & + & + & + & + \\
\hline Unemployment rate & + & + & + & + & + & + & + & + & + & + \\
\hline$\sharp$ of obs. & 4466 & 1886 & 2580 & 3853 & 613 & 2323 & 1549 & 1065 & 820 & 1536 \\
\hline Log-likelihood & -7354.207 & -3186.001 & -4105.709 & -6251.685 & -1077.439 & -3853.416 & -2495.687 & -1801.479 & -1227.073 & -2556.856 \\
\hline
\end{tabular}

Note: p-values are in parenthesis. The suffix "st" represents the standardized values of the variable. * Year dummies for the unemployment entrance year and national unemployment rate at the year of entrance in to the unemployment. 
Table A5: Regression Results for Employment Durations

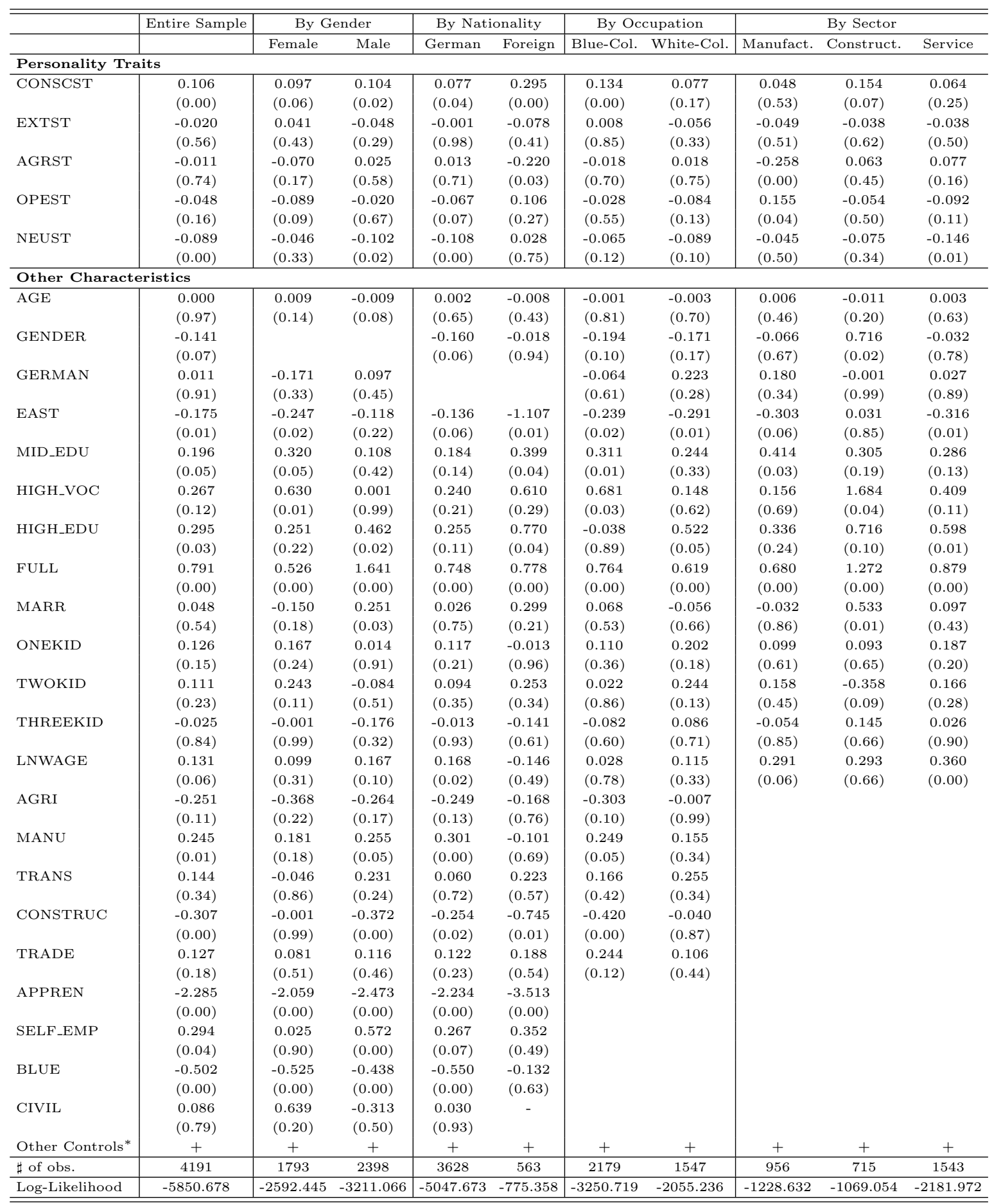

Note: p-values are in parenthesis. The suffix "st" represents the standardized values of the variable. * Year dummies for the employment entrance year. 


\section{Appendix B. Figures}

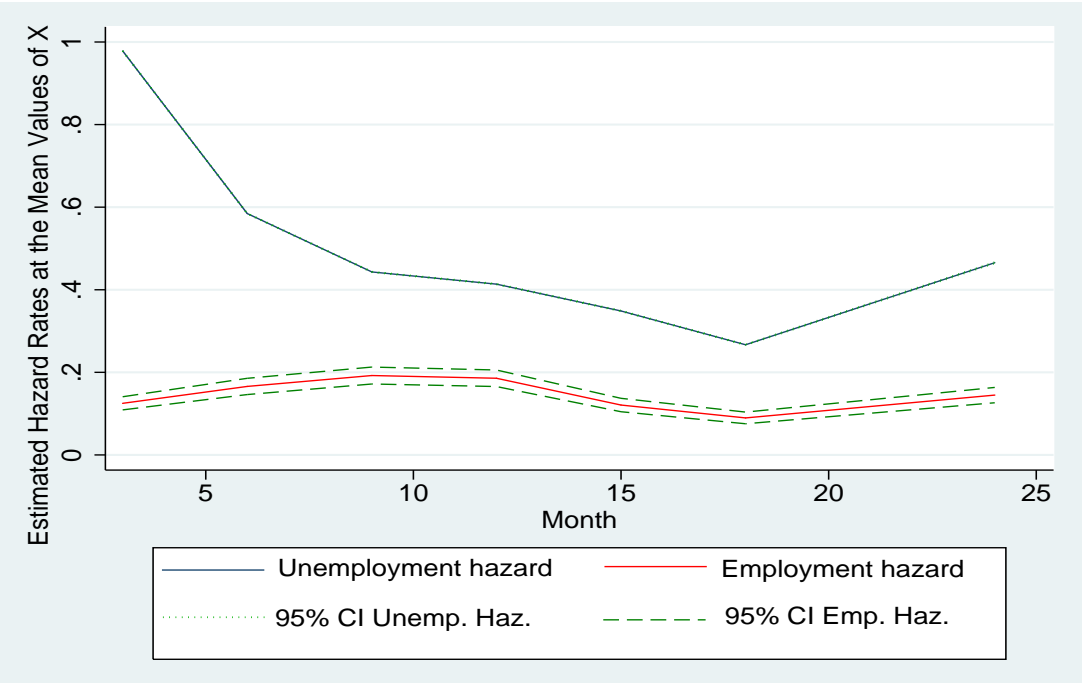

Figure B1: Hazard rate with 95 percent confidence band. Estimates are based on more general specification of unemployment and employment hazards.
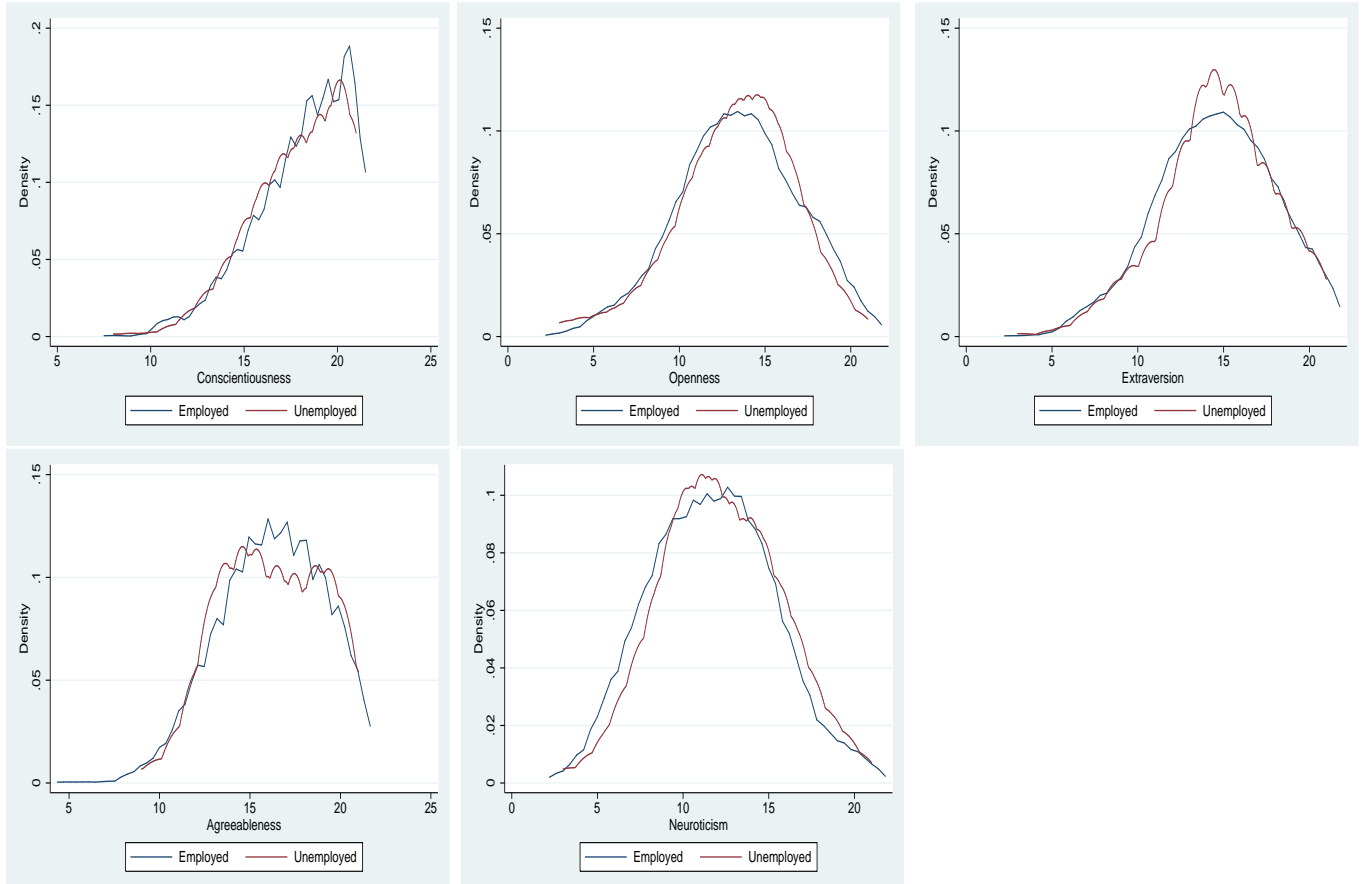

Figure B2: Distribution of the Big Five Personality Traits in the Sample (SOEP, 2005) using a Gaussian Kernel with a bandwidth chosen by Silverman's rule of thumb. 